\title{
Kesulitan Pembelajaran Daring Matematika Pada Masa Pandemi COVID- 19 di SMP Muslimin Cililin
}

\author{
Alwan Fauzy ${ }^{1}$, Puji Nurfauziah ${ }^{2}$ \\ ${ }^{1,2}$ IKIP SILIWANGI, Jl. Terusan Jendral Sudirman, Cimahi Tengah, Kota Cimahi, Jawa Barat \\ fauzyalwan64@gmail.com
}

\begin{abstract}
The COVID-19 pandemic has impacted various fields in the world, including education. This situation has led to a change in learning that is usually face-to-face in the classroom to be carried out at home, namely online learning. During online learning, many students find it difficult to implement, especially in mathematics lessons. Because of this, the purpose of this study was to determine the difficulties of students when learning mathematics online at SMP Muslimin Cililin. The method used in this research is descriptive qualitative, data collection techniques with survey methods, namely by distributing online questionnaires. The subjects of this study were students of class VIII which consisted of five different classes, class VIII A, VIII B, VIII C, VIII D, and VIII E which consisted of 51 respondents. Based on the analysis of the results from the online questionnaire, it was found that most students use WhatsApp as a medium when learning online, a common obstacle that students experience during online learning is dominated by inadequate internet networks and full cellphone memory. In addition, mathematics is also hard and challenge for students when learning online due to several factors, namely: (1) limited interaction space with teachers, (2) the number of formulas used in mathematics, (3) the objects studied in mathematics have the abstract pattern.
\end{abstract}

Keywords: Mathematics, The Covid-19 Pandemic, Online Learning

\begin{abstract}
Abstrak
Pandemi COVID-19 telah berdampak pada berbagai bidang di dunia, tanpa terkecuali bidang pendidikan. Situasi ini menyebabkan berubahnya pembelajaran yang biasanya tatap muka di ruang kelas menjadi dilaksanakan dirumah, yaitu dengan pembelajaran daring. Pada saat pembelajaran daring, banyak siswa merasa kesulitan dalam pelaksanaannya, khususnya pada pelajaran matematika. Oleh karena hal tersebut, tujuan dari penelitian ini adalah untuk mengetahui kesulitan-kesulitan siswa pada saat pembelajaran daring matematika di SMP Muslimin Cililin. Metode yang digunakan dalam penelitian ini adalah kualitatif deskriptif, teknik pengumpulan data dengan metode survey, yaitu dengan menyebarkan angket online. Subjek dari penelitian ini adalah siswa kelas VIII yang terdiri dari lima kelas yang berbeda, kelas VIII A, VIII B, VIII C, VIII D, dan VIII E yang terdiri dari 51 responden. Berdasarkan analisis hasil dari angket online, didapatkan hasil bahwa kebanyakan siswa menggunakan WhatsApp sebagai media saat pembelajaran daring, kendala umum yang di alami siswa selama pembelajaran daring di dominasi jaringan internet yang tidak memadai dan memori HP yang penuh. Selain itu, matematika juga menjadi kesulitan dan tantangan tersendiri bagi siswa saat pembelajaran daring dikarenakan beberapa faktor, yaitu: (1) terbatasnya ruang interaksi dengan guru, (2) banyaknya rumus yang digunakan dalam matematika, (3) objek yang di pelajari dalam matematika memiliki pola abstrak.
\end{abstract}

Kata kunci: Matematika, Pandemi Covid-19, Pembelajaran Daring

Copyright (c) 2021 Alwan Fauzy, Puji Nurfauziah

$\triangle$ Corresponding author: Alwan Fauzy

Email Address: fauzyalwan64@gmail.com (Jl. Terusan Jendral Sudirman, Cimahi, Jawa Barat, Indonesia)

Received 11 Februari 2021, Accepted 12 Maret 2021, Published 17 Maret 2021

\section{PENDAHULUAN}

Dunia tengah digemparkan dengan adanya penyebaran wabah COVID-19 yang begitu cepat dan masif telah menyebabkan puluhan juta orang terinfeksi dan menyebar di ratusan negara di dunia. Penyebaran COVID-19 telah mempengaruhi berbagai bidang diseluruh dunia, khususnya bidang pendidikan di Indonesia (Herliandry, Nurhasanah, Suban, \& Kuswanto, 2020). Pendidikan merupakan sebuah proses dalam kehidupan manusia sebagai sarana untuk mendapatkan ilmu pengetahuan yang kelak akan berguna untuk menopang kehidupan dimasa yang akan dating. Menurut Sumiati \& Agustini (2020) berpendapat bahwa pendidikan ialah suatu hal yang penting bagi kehidupan dan mempunyai 
peran sebagai wadah guna mengembangkan kemampuan dan potensi bagi diri manusia. Dikarenakan pandemic tersebut, banyak negara di dunia memutuskan untuk sementara waktu memberhentikan sekolah dari tingkat taman kanan-kanak hingga setingkat perguruan tinggi, termasuk di Indonesia (Syah, 2020).

Berdasarkan permasalahan diatas, pemerintah melalui Peraturan Menteri Kesehatan Nomor 9 Tahun 2020 berusaha untuk meminimlisir penyebaran virus tersebut dengan upaya mengeluarkan larangan untuk berkerumun dan memberlakukan PSBB hampir disetiap daerah di Indonesia. Selain itu, kondisi saat ini mengharuskan warganya untuk beribadah, bekerja dan belajar dari rumah masingmasing (Jamaluddin, Ratnasih, Gunawan, \& Paujiah, 2020). Karena menyebarnya wabah Covid-19 ini menyebab kegiatan belajar mengajar tidak bisa diselenggaran di dalam kelas, sebagaimana yang di ungkapkan Ambiyar, Aziz, \& Melisa (2020) mengemukakan "proses pembelajaran menjadi terganggu dan tidak dapat dilakukan secara konvensional karena adanya pandemi Covid-19”. Kondisi ini, menyebabkan para pemangku pendidikan harus merancang alternatif pembelajaran jarak jauh. Cara tersebut dilakukan supaya pelaksana pembelajaran memiliki berbagai jenis alternatif dalam menyampaikan pembelajaran kepada siswa (Ramanta \& Dwi Widayanti, 2020). Hal tersebut diperkuat dengan Surat Edaran (SE) Menteri bidang Pendidikan dan kebudayaan Tahun 2020 Nomor 36962/MPK.A/HK/2020, menginstruksikan agar proses belajar mengajar dilakukan secara daring dalam upaya pencegahan penyebaran COVID-19.

Pembelajaran daring ialah sebuah pembelajaran yang dilakukan secara jarak jauh berbantuan media internet dan perangkat bantu lainnya seperti telepon seluler, laptop dan komputer (Putria, Maula, \& Uswatun, 2020). Artinya, bahwa pelaksanaan pembelajaran daring memakai unsur teknologi sebagai sarana dan internet sebagai sistem (Fitriyani, Fauzi, \& Sari, 2020). Setyorini (Handayani, 2020) menjelaskan keuntungan dari pembelajaran daring adalah waktu tidak terbatas, masih banyak waktu luang dan menghemat biaya transportasi. Akan tetapi dalam praktinya, pembelajaran daring tidak semaksimal pembelajaran dikelas, terutama pada pelajaran matematika. Matematika ialah salah satu ilmu yang sangat diperlukan dalam kehidupan manusia, karena melalui matematika ini siswa dilatih agar mampu berpikir dengan sistematis, logis, kritis, dan mampu menyelesaikan masalah yang dihadapinya dalam kehidupan nyata (Yunitasari, Sahrudin, Kartasasmita, \& Prakoso, 2019).

Karena itu, pelajaran matematika sangat perlu ajarkan kepada seluruh siswa mulai dari tingkat sekolah dasar hingga tarap perguruan tinggi, agar siswa mempunyai kemampuan berpikir secara logis, sistematis, analitis, kreatif, serta bisa bekerjasama dengan baik. Astuti \& Sari (2017) menyatakan bahwa matematika merupakan suatu keterampilan intelektual yang melibatkan kemampuan bernalar, berpikir sistematis, cermat, kritis dan kreatif. Sedangkan menurut Annur \& Hermansyah (2020) mengemukakan bahwa pembelajaran matematika adalah pembelajaran yang penting dalam upaya mempersiapkan Sumber Daya Manusia (SDM) untuk berkompetensi di era global. Tujuan dari mempelajari matematika diantaranya untuk mengembangkan kemampuan mengukur, berhitung, menganalisis dan menggunakan rumus (Hendra, 2018). Disamping pentingnya mempelajari matematika, dalam kenyataannya 
matematika masih di anggap suatu pelajaran yang sulit dan rumit. Menurut Amallia \& Unaenah (2018) menyatakan bahwa masih banyak siswa yang menganggap matematika sebagai pelajaran yang sulit, sehingga menyebabkan siswa mudah menyerah sebelum mempelajari matematika. Selain itu, adanya pembelajaran daring yang terkesan mendadak karena COVID-19 ini juga menyebabkan persiapan yang tidak optimal. Sehingga menyebabkan siswa merasa tidak siap dalam pelaksanaanya, terutama dalam mata pelajaran matematika. Berdasarkan uraian permasalah diatas, maka diperlukan suatu kajian untuk mengetahui keadaan dan kesulitan pembelajaran daring matematika yang di laksanakan di sekolah menengah pertama (SMP). Maka dari itu, peneliti bertujuan untuk menganalisis kesulitan pembelajaran daring matematika saat pandemi COVID-19 pada siswa SMP Kelas VIII di SMP Muslimin Cililin.

\section{METODE}

Metode penelitian yang digunakan adalah kualitatif deskriptif, untuk memberikan gambaran pembelajaran daring di SMP Muslimin Cililin. Penelitian kualitatif merupakan metode penelitian naturalistic dikarenakan penelitiannya dilaksanakan pada kondisi yang apa adanya (natural setting) (Sugiyono, 2015:14). Teknik untuk mengumpulkan data dengan metode survey, yaitu dengan melakukan penyebaran angket secara online. Angket tersebut disebarkan secara acak kepada responden melalui Google Form yang dikirimkan melalui pesan WhatsApp. Subjek penelitian ialah siswa kelas VIII di SMP Muslimin Cililin yang terdiri dari lima kelas yang berbeda, yaitu VIII A, VIII B, VIII C, VIII D, VIII E. Total responden yang berhasil mengisi angket sampai tenggat waktu yang telah dijadwalkan adalah sebanyak 51 responden. Adapun indikator dari angket yang disebarkan terdiri dari: Kondisi pembelajaran daring, kendala pembelajaran daring, dan kesulitan pembelajaran daring matematika. Hasil dari isian angket kemudian dipersentasekan dan di deskripsikan sesuai dengan indikator-indikator yang terdapat di dalam angket.

Tabel 1. Kisi-kisi Angket

\begin{tabular}{|c|l|c|}
\hline No & \multicolumn{1}{|c|}{ Aspek } & Nomor \\
\hline $\mathbf{1}$ & Kondisi pembelajaran daring & $1,2,3$ \\
\hline $\mathbf{2}$ & Kendala pembelajaran daring & 3,4 \\
\hline $\mathbf{3}$ & Kesulitan pembelajaran daring matematika & $5,6,7$ \\
\hline & Total & 7 \\
\hline
\end{tabular}

\section{HASIL DAN DISKUSI}

Instrumen yang menjadi rujukan untuk mengidentifikasi kesulitan pembelajaran daring matematika di SMP Muslimin Cililin adalah dengan cara menyebarkan angket online, via google form yang di sebar kepada siswa lewat whatssapp grup. Angket disebarkan kepada lima kelas di Kelas VIII SMP Muslimin Cililin secara online via whatsapp grup. Rekapitulasi responden yang mengisi angket tergambar pada tabel dibawah ini. 
Tabel 2. Rekapitulasi Responden

\begin{tabular}{|r|c|c|c|}
\hline No. & Kelas & Persentase & Jumlah siswa \\
\hline $\mathbf{1}$ & VIII A & $29,4 \%$ & 15 \\
$\mathbf{2}$ & VIII B & $23,5 \%$ & 12 \\
$\mathbf{3}$ & VIII C & $0 \%$ & 0 \\
$\mathbf{4}$ & VIII D & $27,5 \%$ & 14 \\
$\mathbf{5}$ & VIII E & $19,6 \%$ & 10 \\
\hline & Total & $100 \%$ & 51 \\
\hline
\end{tabular}

Berdasarkan rekapitulasi pada tabel 1 diatas, bahwa rekapitulasi responden kelas VIII SMP Muslimin-Cililin sebanyak 51 responden yang mengisi angket pembelajaran daring. Berdasarkan hasil angket yang disebar, ditemukan beberapa hasil terkait pembelajaran daring. Pada Indikator pertama, yaitu kondisi pembelajaran daring digambarkan dengan tiga item pernyataan yang diterapkan pada no 1, 2 dan3. Berdasarkan hasil data yang diperoleh angket No. 1 tentang "apakah siswa mengikuti pembelajaran daring?". Didapatkan hasil bahwa masih banyak siswa yang mengikuti pembelajaran secara daring, datanya bisa dilihat pada gambar 1 berikut.

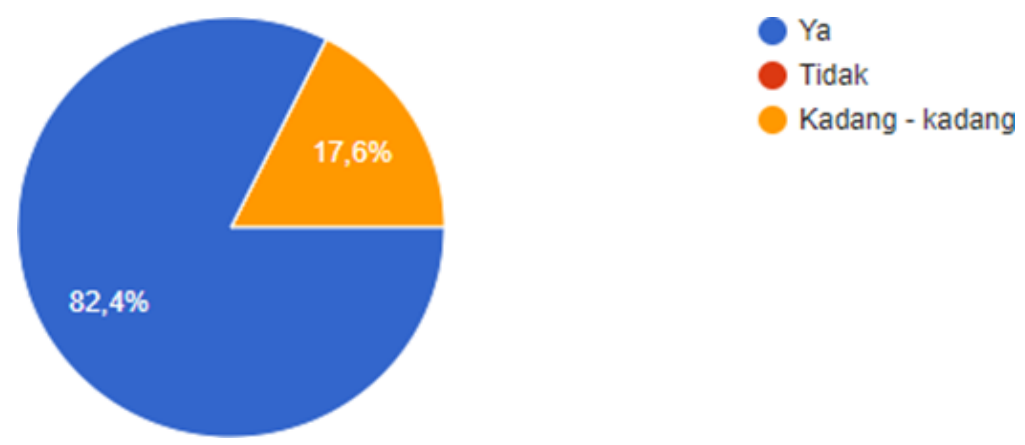

\section{Gambar 1. Persentase Siswa yang Mengikuti Pembelajaran Daring}

Pada gambar 1, dapat di simpulkan bahwa minat untuk pembelajaran daring masih tinggi dengan persentase hampir $85 \%$. Pada saat kegiatan pembelajaran daring, jelas pastinya menggunakan perangkat lunak atau aplikasi sebagai sarana belajar. Pada angket No.2 peneliti menanyakan tentang "aplikasi apa yang paling diminati ketika pembelajaran daring ?". Berdasarkan hasil yang di dapat menempatkan WhatsAapp sebagai aplikasi yang penggunaannya paling tinggi, sebagaimana pada data gambar 2 berikut.

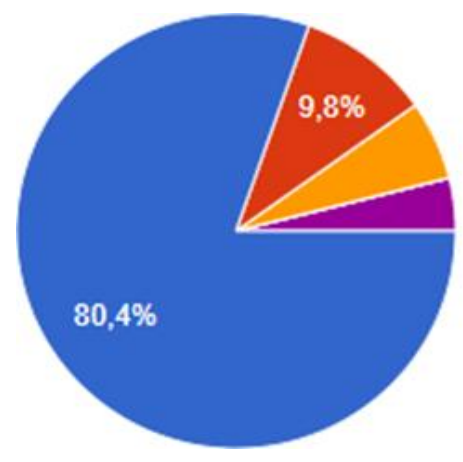

WhatsApp

Google Classroom

Zoom

Edmodo

lainnya

Gambar 2. Aplikasi yang Diminati Ketika Pembelajaran Daring 
Seperti yang terlihat pada gambar 2, WhatsApp menjadi aplikasi yang paling diminati ketika pembelajaran daring dengan persentase lebih dari $80 \%$. Oleh karena itu, bisa disimpulkan bahwa WhatsApp menjadi aplikasi paling banyak digunakan ketika pembelajaran daring dikarenakan apliksai tersebut sudah sangat familiar dikalangan banyak orang. Sejalan dengan hal tersebut, Dewi, Gunawan et al., Purwanto et al., (Setyorini, 2020), mengatakan bahwa pembelajaran daring saat ini paling banyak dilakukan menggunakan aplikasi WhatsApp dikarenakan rata-rata guru dan siswa memiliki aplikasi WhatsApp di Handphone nya masing-masing. Selain itu, diantara kelebihan WhatsApp adalah ketika jaringan sedang tidak stabil pun WhatsApp tetap bisa digunakan untuk pembelajaran daring. Menurut hasil wawancara Anhusadar (2020) mengungkapkan bahwa "Menggunakan Media aplikasi Whatsapp lebih irit paket data dan tetap bisa digunakan walaupun jaringan sedang tidak mendukung". Aplikasi paling diminati ketika pembelajaran daring setelah WhatsApp adalah Google Classroom. Hal ini dikarenakan Google Classroom hampir sama familiar nya dengan WhatsApp dalam dalam konteks pembelajaran daring. Selain itu, kedua aplikasi ini tidak menghabiskan banyak kuota dan materi yang diunggah melalui WhatsApp dan Google Classroom dapat dengan mudah di unggah (Kusumaningrum $\&$ Wijayanto, 2020). Sisanya responden memilih zoom dan aplikasi lainnya sebagai aplikasi yang paling diminati ketika pembelajaran daring.

Selanjutnya pada angket No. 3 ditanyakan tentang "Format penugasan yang sering digunakan guru ketika pembelajaran daring?". Untuk melihat hasil penelitian terkait format penugasan dari guru dapat diamati pada gambar 3.
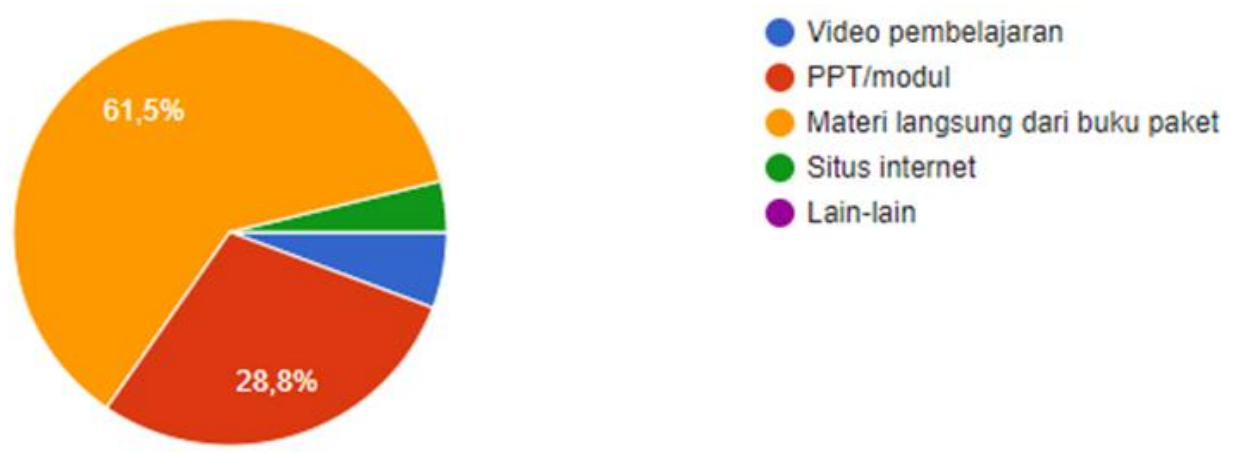

Gambar 3. Persentase Bentuk Format Penugasan Dari Guru

Berdasarkan gambar 3, dapat diambil kesimpulan bahwa guru lebih sering untuk memberikan tugas dengan cara mengambil langsung dari buku paket, dibuktikan dengan persentase lebih dari $60 \%$. Maksud mengambil langsung dari buku paket adalah guru memfoto atau meng Screenshot materi yang ada di buku paket, untuk selanjutnya diberikan kepada siswa. Hal ini dikarenakan terbatasnya kapasitas guru untuk mengeksplor dan menerangkan lebih jauh terkait materi yang sedang diajarkan kepada siswa. Oleh karena itu, guru mengusahakan pemberian tugas disesuaikan dengan buku pegangan siswa dan guru (Putria et al., 2020). Adapun format penugasan urutan kedua adalah berupa PPT/modul, dibuktikan dengan persentasenya yang hampir $30 \%$. Menurut Alimin \& Effendi (2020), "Modul merupakan suatu media pembelajaran yang berisi tentang kumpulan bahan ajar kompleks yang 
disajikan dalam bentuk "Self-Intruction". Salah satu keunggulan dari PPT/modul adalah kumpulan materinya yang sudah dibuat sedemikian rupa agar mudah dipahami oleh siswa dan ukuran file nya yang relatif kecil, sehingga tidak memerlukan kuota yang besar untuk mengunduhnya.

Pada indikator kedua mengenai kendala pembelajaran daring, tergambar pada pernyataan no 4 dan 5. Terlihat pada angket No.4 peneliti mengajukan pertanyaan "apa kendala yang dialami ketika pembelajaran daring?", untuk hasil data yang diperoleh dari para responden dapat dilihat pada gambar 4.

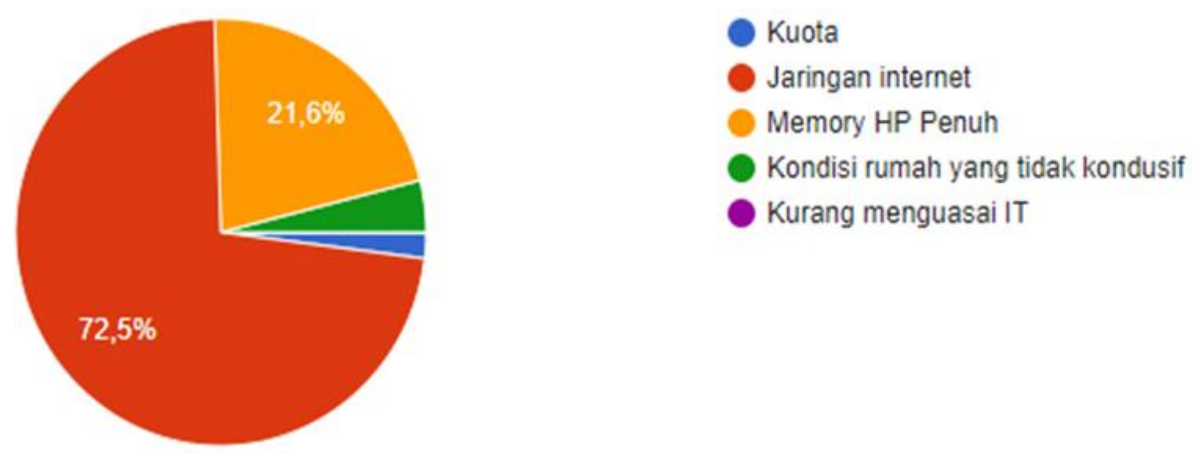

Gambar 4. Persentase Kendala Pembelajaran Daring

Berdasarkan data yang diperoleh pada gambar 4, dapat diketahui bahwa jaringan internet menjadi kendala yang paling besar dialami oleh siswa, dengan persentase hampir 75\%. Jaringan internet menjadi salah satu unsur penting untuk mendukung terlaksananya pembelajaran daring. Hal tersebut senada dengan yang diungkapka Handayani (2020), menyatakan bahwa jaringan internet merupakan faktor penting bagi lingkungan pembelajaran daring. Tanpa adanya adanya jaringan internet yang baik, maka pembelajaran daring yang dilaksanakan tidak bisa berjalan maksimal. Faktor penyebab sulitnya siswa dalam mengakses internet dikarenakan lokasi tempat tinggal siswa yang berada jauh dari jangkauan jaringan internet dan bisa di pengaruhi oleh keadaan cuaca yang tidak baik. Senada dengan pendapat tersebut, Khasanah, Pramudibyanto, \& Widuroyekti (Kusumaningrum \& Wijayanto, 2020), mengungkapkan bahwa faktor yang mengakibatkan sulitnya jaringan internet dipengaruhi oleh kondisi alam, yaitu saat terjadi hujan atau cuaca buruk. Kendala selanjutnya yang dialami siswa setelah jaringan internet adalah memori HP (Handphone) penuh. Handphone adalah perangkat keras yang menjadi salah satu faktor pendukung utama agar bisa terlaksananya pembelajaran daring. Menurut Purwanto et al., (Putria et al., 2020), menyatakan bahwa tanpa adanya Handphone pembelajaran daring tidak bisa dilaksanakan. Walaupun sebenarnya dengan tanpa adanya Handphone pun pembelajaran daring tetap bisa dilaksanakan, yaitu dengan menggunakan perangkat keras lain seperti laptop atau Komputer. Hanya saja karena harganya yang relatif lebih mahal dan hanya orang-orang tertentu yang memilikinya, menyebabkan Handphone memiliki peran yang signifikan dalam pembelajaran daring.

Pada indikator ketiga, yaitu mengenai kesulitan pembelajaran daring pada pembelajaran matematika tergambar pada pernyataan no 5, 6, dan 7 pada angket yang disebarkan. Matematika menjadi ilmu yang memiliki peran signifikan dalam kehidupan manusia, baik teknologi maupun dalam 
membangun daya pikir manusia yang sistematis. Menurut Lamote (2017), berpendapat bahwa matematika merupakan ilmu universal dan menjadi dasar berkembangnya ilmu pengetahuan, teknologi modern, dan memajukan pemikiran serta analisa manusia. Akan tetapi, dalam kenyataannya matematika masih ada siswa yang kurang meminati matematika, terutama pada saat pembelajaran daring. Untuk mengetahui hal tersebut, peneliti mengajukan angket terbuka tentang "Mata pelajaran apa yang paling tidak diminati ketika pembelajaran daring?". Untuk melihat data yang diperoleh bisa dilihat pada gambar 4 berikut.

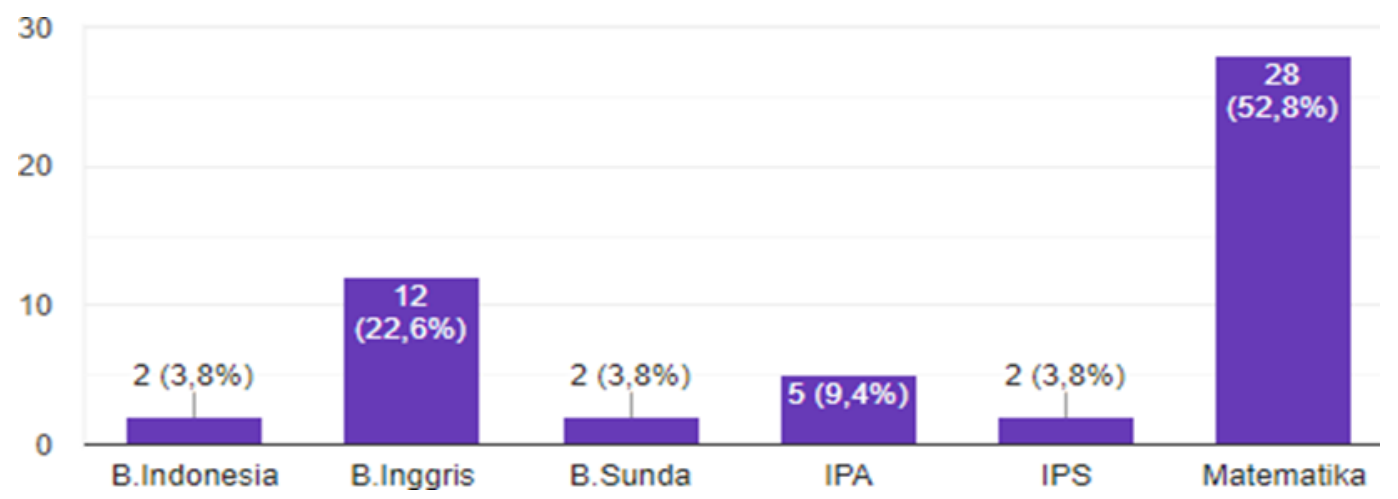

Gambar 5. Mata Pelajaran yang Tidak Diminati Selama Pembelajaran Daring

Berdasarkan gambar 5 tersebut, dapat diketahui bahwa matematika menjadi mata pelajaran yang paling tidak diminati pada saat pembelajaran daring, dengan persentase hampir $55 \%$. Tingginya persentase matematika sebagai suatu pelajaran yang tidak diminati dikarenakan soal-soalnya yang terkesan sulit dan rumit. Matematika menjadi salah satu pelajaran yang mendapat perhatian khusus dalam proses pembelajaran disekolah karena masih banyaknya siswa yang merasa kesulitan dalam menyelesaikan soalnya (Dwidarti, Mampouw, \& Setyadi, 2019).

Selanjutnya untuk mengetahui tingkatan pemahaman siswa pada pembelajaran matematika daring, angket yang diajukan berupa “Apakah kamu paham ketika pembelajaran matematika daring?”. Data yang diperoleh dapat diamati pada gambar 6 berikut.

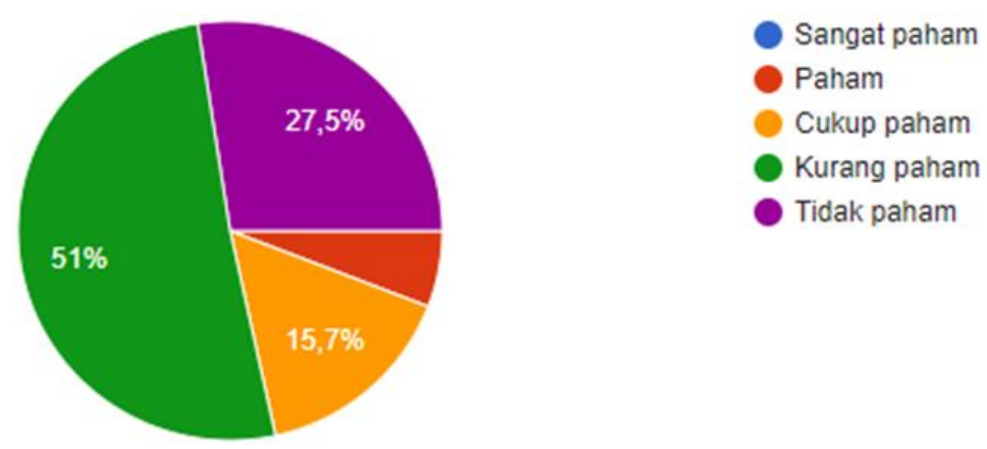

Gambar 6. Persentase Tingkat Pemahaman Siswa Pada Pembelajaran Daring Matematika 
Berdasarkan gambar 6, diketahui bahwa tingkatan pemahaman siswa pada pembelajaran daring matematika masih sangat rendah. Sebenarnya sebelum pembelajaran daring pun tingkat pemahaman siswa terhadap matematika sudah rendah. Hal tersebut terbukti dari hasil ujian matematika siswa yang dari tahun ke tahun yang semakin menurun. pada tahun pelajaran 2011/2012 nilai rata-rata UN matematika adalah 6,8, sedangkan pada tahun ajaran 2012/2013 adalah 6,12, artinya nilai rata-rata ujian matematika semakin rendah (Sholihah \& Mahmudi, 2015). Senada dengan penelitian Khotimah (2019), menjelaskan bahwa hasil UN tahun 2018, matematika menjadi salah satu bidang studi yang nilai rataratanya mengalami penurunan setiap tahunnya. Setiap permasalahan pasti memiliki faktor-faktor yang mendasarinya. karena untuk mengetahui faktor penyebab rendahnya tingkat pemahaman siswa terhadap pembelajaran matematika secara daring, peneliti mengajukan angket sebagai berikut. "Faktor apa penyebab sulitnya pemahaman matematika saat pembelajaran daring?”. Untuk melihat hasil data yang didapat peneliti, dapat diamati pada gambar 7 .
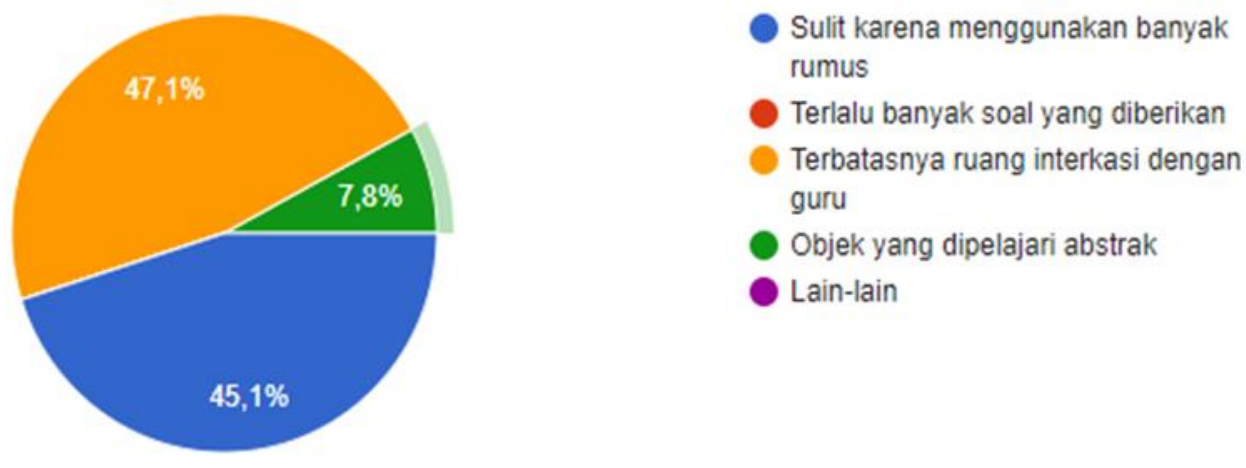

Gambar 7. Faktor Penyebab Kesulitan Dalam Pembelajaran Daring Matematika

Berdasarkan gambar 7, bisa diketahui bahwa terbatasnya ruang interaksi dengan guru menjadi faktor tertinggi yang menyebabkan rendahnya tingkat pemahaman siswa terhadap pembelajaran daring matematika, dengan persentase hampir $50 \%$. Hal tersebut dikarenakan kurangnya interaksi antara guru dan murid sehingga menyebabkan guru tidak sepenuhnya bisa mengontrol keadaan akademik siswa. Menurut Hartono, 2017 (Setiawan \& Aden, 2020) mengemukakan bahwa sistem pembelajaran daring mengurangi interaksi sosial antara pendidik dan peserta didik yang berakibat pada kurangnya kontrol akademik dan sosial. Selanjutnya kesulitan memahami pembelajaran matematika daring karena banyak rumus menempati persentase kedua tertinggi dengan angka 45,1\%. Oleh karena itu, dapat disimpulkan bahwa rendahnya pemahaman siswa terhadap matematika dikarenakan matematika merupakan pelajaran yang menggunakan banyak rumus untuk pengerjaanya. Pernyataan tersebut senada dengan hasil observasi yang dilakukan Khotimah (2019), "masih ada siswa yang mengatakan bahwa matematika ialah pelajaran yang sulit karena banyak rumus yang harus dihapalkan". Faktor lain penyebab rendahnya pemahaman pembelajaran daring matematika siswa dikarenakan objek yang dipelajarinya abstrak. Chambers, 2008 (Novferma, 2016) Mengungkapkan matematika merupakan suatu bidang ilmu yang erat kaitannya dengan pola-pola abstrak yang memiliki ciri khas untuk memecahkan masalah. 
Berbagai kesulitan pembelajaran daring, kiranya dapat memicu semangat para guru untuk terus melakukan inovasi demi inovasi dalam pembelajaran khususnya dalam pelajaran daring matematika, sehingga pembelajaran akan menjadi lebih baik. Selain itu, pemanfaatan faktor pendukung semaksimal mungkin juga dapat meningkatkan kreatifitas dan perkembangan siswa dalam melaksanakan pembelajaran daring (Putria et al., 2020). Adapun solusi yang bisa menjadi alternatif guru untuk menghadapi permasalah pembelajaran daring adalah dengan berupaya sebaik mungkin untuk menyajikan pembelajaran yang menarik, kreatif dan menyenangkan, terutama pada pembelajaran matematika. Hal tersebut senada dengan Anugrahana (2020) mengemukakan bahwa upaya mengatasi permasalahan pembelajaran daring salah satunya dengan cara mendorong guru untuk kreatif dan inovatif dalam menciptakan pembelajaran daring yang menarik bagi siswa. Menurut Utami \& Cahyono (2020), mengungkapkan bahwa solusi dari kesulitan pembelajaran matematika e-learning (daring) adalah dengan menerapkan pembelajaran e-learning yang menarik, efektif dan menyenangkan. Selanjutnya ialah dengan memaksimalkan ketersediaan fasilitas teknologi yang sudah ada, sehingga pembelajaran daring dapat berjalan sesuai dengan yang direncanakan sebelumnya.

\section{KESIMPULAN}

Berdasarkan pembahasan dari hasil penelitian yang sudah selesai dilakukan, dapat disimpulkan bahwa kebanyakan siswa menggunakan aplikasi WhatsApp sebagai media ketika pembelajaran daring. Terkait kendala yang dihadapi siswa ketika sedang pembelajaran daring didominasi dengan jaringan internet yang tidak memadai dan memori HP penuh. Selain itu, matematika juga menjadi kesulitan dan tantangan tersendiri bagi siswa ketika melaksanakan pembelajaran daring. Adapun kesulitan yang dihadapi siswa di SMP Muslimin Cililin ketika pembelajaran daring matematika dikarenakan beberapa faktor, yaitu : (1) Terbatasnya ruang interaksi antara guru dan siswa yang menyebabkan pembelajaran tidak maksimal, (2) Banyaknya rumus yang dipakai dalam pembelajaran matematika menyulitkan siswa untuk memahami materi tersebut, (3) Objek yang dipelajari berupa pola-pola abstrak, sehingga semakin menyulitkan siswa untuk memahami materi tersebut. Dengan memperhatikan penjabaran terkait kesulitan pembelajaran daring matematika yang dihadapi siswa di SMP Muslimin Cililin, solusi yang dianggap bisa dikerjakan untuk memecahkan permasalahan tersebut adalah dengan membuat pembelajaran daring matematika lebih menarik, efektif dan menyenangkan. Hasil penelitian yang telah dilaksanakan menjadi dasar bagi peneliti untuk melaksanakan penelitian lanjutan mengenai kesulitan pembelajaran daring matematika pada siswa kelas VIII di SMP Muslimin Cililin.

Akhir kata, peneliti menyarankan kepada para peneliti lain untuk menggali dan mengeksplor lebih jauh terkait kesulitan pembelajaran daring matematika. Dikarenakan saat situasi pandemi seperti sekarang ini dibutuhkan penelitian-penelitian yang komprehensif untuk mencari tahu adaptasi yang baik ketika pembelajaran daring. 


\section{UCAPAN TERIMAKASIH}

Ucapan terimakasih disampaikan kepada IKIP Siliwangi selaku instansi tempat peneliti menempuh pendidikan, SMP Muslimin Cililin yang sudah memfasilitasi penelitian dan kepada segenap pihak yang telah turut serta membantu terlaksananya penelitian ini.

\section{REFERENSI}

Alimin, A., \& Effendi, H. (2020). Pengembangan Modul Pembelajaran Berbasis Daring Pada Mata Diklat Instalasi Penerangan Listrik KKelas XI di Sekolah Menengah Kejuruan. Journal of Multidicsiplinary Research and Development, 2(4), 133-138.

Amallia, N., \& Unaenah, E. (2018). Analisis Kesulitan Belajar Matematika Pada Siswa Kelas III Sekolah Dasar. Attadib Journal Of Elementary Education, 3(2), 123-133. Retrieved from https://www.jurnalfai-uikabogor.org/index.php/attadib/article/view/414

Anhusadar, L. O. (2020). Persepsi Mahasiswa PIAUD Terhadap Kuliah Online di Masa Pandemi Covid 19. KINDERGARTEN: Journal of Islamic Early Childhood Education, 3(1), 44-58. https://doi.org/10.24014/kjiece.v3i1.9609

Annur, M. F., \& Hermansyah. (2020). Analisis Kesulitan Mahasiswa Pendidikan Matematika Dalam Pembelajaran Daring Pada Masa Pandemi COVID-19. Jurnal Kajian, Penelitian Dan Pengembangan Kependidikan, 11, 195-201.

Anugrahana, A. (2020). Hambatan, Solusi dan Harapan: Pembelajaran Daring Selama Masa Pandemi Covid-19 Oleh Guru Sekolah Dasar. Scholaria: Jurnal Pendidikan Dan Kebudayaan, 10(3), 282289. https://doi.org/10.24246/j.js.2020.v10.i3.p282-289

Fitriyani, Y., Fauzi, I., \& Sari, M. Z. (2020). Motivasi Belajar Mahasiswa Pada Pembelajaran Daring Selama Pandemik Covid-19. Profesi Pendidikan Dasar, 6(2), 161-175. https://doi.org/10.23917/ppd.v7i1.10973

Handayani, L. (2020). Keuntungan , Kendala dan Solusi Pembelajaran Online Selama Pandemi Covid19: Studi Ekploratif di SMPN 3 Bae Kudus. Journal Industrial Engineering \& Management Research (JIEMAR), I(Juli), 15-23. Retrieved from https://www.jiemar.org/index.php/jiemar/article/view/36/24

Herliandry, L. D., Nurhasanah, Suban, M. E., \& Kuswanto, H. (2020). Pembelajaran Pada Masa Pandemi Covid-19. Jurnal Teknologi Pendidikan, 22(1), 65-70. https://doi.org/https://doi.org/10. 21009/jtp.v22i1.15286

Jamaluddin, D., Ratnasih, T., Gunawan, H., \& Paujiah, E. (2020). Pembelajaran Daring Masa Pandemik Covid-19 Pada Calon Guru: Hambatan, Solusi dan Proyeksi. Karya Tulis Ilmiah,Lembaga Penelitian Dan Pengabdian Kepada Masyarakat UIN Sunan Gunung Djati Bandung, 2020, 1-10. Retrieved from http://digilib.uinsgd.ac.id/30518/

Khotimah, H. (2019). Faktor-Faktor Yang Memengaruhi Belajar Matematika. De Fermat: Jurnal Pendidikan Matematika, 2(2), 116-123. https://doi.org/10.36277/defermat.v2i2.56

Kusumaningrum, B., \& Wijayanto, Z. (2020). Apakah Pembelajaran Matematika Secara Daring Efektif? (Studi Kasus pada Pembelajaran Selama Masa Pandemi Covid-19). Kreano, Jurnal Matematika Kreatif-Inovatif, 11(2), 136-142. Retrieved from https://journal.unnes.ac.id/nju/index.php/kreano/article/view/25029

Lamote, H. (2017). Kesulitan-kesulitan Guru Matematika Dalam Melaksanakan Pembelajaran Kurikulum 2013 di Madrasah Aliyah DDI Labibia. Jurnal Al-Ta'dib, 10(1), 55-72. 
Novferma, N. (2016). Analisis Kesulitan dan Self-Efficacy Siswa SMP Dalam Pemecahan Masalah Matematika Berbentuk Soal Cerita. Jurnal Riset Pendidikan Matematika, 3(1), 76-87.

Putria, H., Maula, L. H., \& Uswatun, D. A. (2020). Analisis Proses Pembelajaran Dalam Jaringan (DARING) Masa Pandemi COVID-19 pada Guru Sekolah Dasar. JURNAL BASICEDU, 4(4), 861-872. https://doi.org/10.31004/basicedu.v4i4.460

Ramanta, D., \& Dwi Widayanti, F. (2020). Pembelajaran Daring di Sekolah Menengah Kejuruan Putra Indonesia Malang pada Masa Pandemi COVID-19. Prosiding Seminar Bimbingan Dan Konseling, $O(0), 61-67$. Retrieved from http://conference.um.ac.id/index.php/bk2/article/view/81

Setiawan, T. H., \& Aden. (2020). Efektifitas Penerapan Blended Learning Dalam Upaya Meningkatkan Kemampuan akademik Mahasiswa Melalui Jejaring Schology Di Masa Pandemi Covis-19. Jurnal Pembelajaran Matematika Inovatif, 3(5), 493-506.

Setyorini, I. (2020). Pandemi Covid-19 dan Online Learning: Apakah Berpengaruh Terhadap Proses Pembelajaran Pada Kurukulum 13 ? Journal of Industrial Engineering \& Management Research (JIEMAR), O1(Juni), 95-102.

Sholihah, D. A., \& Mahmudi, A. (2015). Keefektifan Experiential Learning Pembelajaran Matematika MTs Materi Bangun Ruang Sisi Datar. Jurnal Riset Pendidikan Matematika, 2(2), 175-185. https://doi.org/10.21831/jrpm.v2i2.7332

Sugiyono. (2015). Metode Penelitian Pendidikan (Pendekatan Kuantitatif, Kualitatif dan R\&D). Bandung: Alfabeta.

Syah, R. H. (2020). Dampak Covid-19 pada Pendidikan di Indonesia: Sekolah, Keterampilan, dan Proses Pembelajaran. SALAM: Jurnal Sosial Dan Budaya Syar-I, 7(5), 395-402. https://doi.org/10.15408/sjsbs.v7i5.15314

Utami, Y. P., \& Cahyono, D. A. D. (2020). Study At Home: Analisis Kesulitan Belajar Matematika Pada Proses Pembelajaran Daring. Jurnal Ilmiah Matematika Realistik(JI-MR), 1(1), 20-26. 